\title{
Additive antitumor effects of celecoxib and simvastatin on head and neck squamous cell carcinoma in vitro
}

\author{
THOMAS GEHRKE*, AGMAL SCHERZAD*, STEPHAN HACKENBERG, PASCAL ICKRATH, \\ PHILIPP SCHENDZIELORZ, RUDOLF HAGEN and NORBERT KLEINSASSER
}

\begin{abstract}
Department of Otorhinolaryngology, Head and Neck Surgery, University Hospital Wuerzburg, D-97080 Wuerzburg, Germany
\end{abstract}
Received February 4, 2017; Accepted May 19, 2017

DOI: 10.3892/ijo.2017.4071

\begin{abstract}
Lipid-lowering statins as well as non-steroidal antiinflammatory drugs (NSAIDs) have been reported to possess cancer-protective effects in many epidemiologic cohort studies. However, the underlying mechanisms of these findings are mostly unknown. To evaluate possible additive antitumor effects of statins and NSAIDs in vitro, PJ-41 and HLaC78 head and neck squamous cell carcinoma cells (HNSCC) were treated with $40 \mu \mathrm{M}$ celecoxib, $50 \mu \mathrm{M}$ simvastatin or a combination of both. Analysis of tumor viability, proliferation, apoptosis, cell cycle changes and secretion of interleukin-6 (IL-6) and interleukin-8 (IL-8) was conducted via MTT assay, Annexin V-propidium iodide test, cell cycle analysis, colony assay and enzyme-linked immunosorbent assay (ELISA). Celecoxib and simvastatin alone as well as a combined treatment showed a significant reduction in tumor cell viability, proliferation and secretion of IL- 6 and IL-8 compared to the control group. The combined treatment even proved to have significantly greater effects. We postulate that simvastatin and celecoxib have additive antitumor effects on HNSCC in vitro, which warrants further investigation.
\end{abstract}

\section{Introduction}

Squamous cell carcinoma of the head and neck (HNSCC) is one of the most commonly occurring malignancies, and is a major cause of cancer morbidity and mortality worldwide with an estimated incidence of 500,000 per year in the USA (1). The overall 5-year survival rate for pharyngeal and oral squamous cell carcinoma is approximately $60 \%$ in the USA, and has not changed significantly during the past 40 years (2). Due

Correspondence to: Dr Thomas Gehrke, Department of Otorhinolaryngology, Head and Neck Surgery, University Hospital Wuerzburg, Josef Schneider-Str. 11, D-97080 Wuerzburg, Germany E-mail: thomas-gehrke@web.de

\section{${ }^{*}$ Contributed equally}

Key words: celecoxib, simvastatin, squamous cell carcinoma, head and neck, PJ-41 to the increasing spread of the human papillomavirus within the oropharyngeal tract, which represents a new pathogenetic factor, the incidence of HNSCC is estimated to rise even more (3). Thus, there is a tremendous need for new treatment options for HNSCC patients.

Statins are widely used as cholesterol-lowering drugs, being small-molecule inhibitors of 3-hydroxy-3-methylglutaryl coenzyme A (HMG-CoA) reductase (4). In addition to their common use in the treatment of lipid disorders, statins have also demonstrated anticarcinogenic properties in various preclinical in vitro studies $(5,6)$. This has been attributed mainly to the inhibition of isoprenoid and cholesterol synthesis, which are both important processes in the intracellular signaling pathways $(6,7)$. Several observational human studies have reported a potential beneficial effect of statin use against the overall risk of cancer (8-10). Other studies, however, reported no such protective effects $(11,12)$. For several specific cancers, especially for colorectal cancer (13), lung cancer $(14,15)$ and renal cell carcinoma (16), protective effects of statin use have been published.

NSAIDs have also been demonstrated to have a potential chemoprotective effect. This has been explained by an induction of cell cycle arrest in G1-Phase via inhibition of Akt (17), inhibition of $\mathrm{Ca}^{2+}$ ATPase activity (18) or activating p53 and p21 (19). Several studies have reported on a protective effect of Aspirin on colorectal adenoms as well as colorectal carcinomas, even in randomized, double-blinded and placebocontrolled study designs (20-23). For selective cyclooxygenase (COX)-2 inhibitors such as celecoxib or rofecoxib, protective effects could also be demonstrated, again mainly for colorectal carcinoma (24-26). However, since there have been serious cardiovascular complications regarding long-term therapy with COX-2-inhibitors (27-29), the relatively high doses needed for the observed cancer-protective effect are being questioned. Therefore, a combination with other drugs with synergistic effects to reduce the dosage of NSAIDs is warranted.

A combined therapy of statins and NSAIDs has already been demonstrated to have a synergistic effect on the induction of apoptosis in prostate and colorectal cancer cells in vitro $(30,31)$. In vivo, a low-dose combination of atorvastatin and celecoxib was reported to have synergistic antitumor effects on colorectal cancer in a xenograft animal model (32). For colorectal cancer, population-based studies have also shown synergistic cancer-protective effects of a combination 
therapy with statins and NSAIDs compared to the respective monotherapies $(33,34)$. Yet for other entities, for example squamous cell carcinoma, few studies have been conducted to date.

The objective of the present study is to analyze the possible additive effects of the combined use of simvastatin and celecoxib on human HNSCC cells in vitro in terms of viability, cell growth, apoptosis and cell cycle changes. Additionally, secretion of selected interleukins, namely IL-6 and IL-8, was analyzed. IL-6 plays a key role in cell proliferation, apoptosis and differentiation. IL- 6 induces activation of Janus kinase 1/2 (JAK1/2), resulting in phosphorylation of STAT3 at tyrosine-705 (Y705) (35). Activation of IL-6/STAT3 signaling has a significant role in self-renewal and acquisition of malignant features of cancer stem cells (CSC) (36). Furthermore, IL-6 levels are highly elevated in metastatic diseases and increased levels of serum IL- 6 are associated with poor disease outcome and prognosis in human cancers $(37,38)$. IL-8 is reported to be related to different malignancies due to the involvement of thrombophilia and angiogenesis (39). Increased secretion of IL- 8 has been shown to increase the metastatic ability of different cancer entities $(40,41)$. Therefore, analysis of IL-6 and IL-8 was included into the present study.

\section{Materials and methods}

Cell culture. The head and neck squamous carcinoma cell lines PE/CA-PJ 41 and HLaC78 were obtained from ECACC (European Collection of Cell Cultures, Salisbury, Wiltshire, UK). Cells were grown in RPMI-expansion medium (RPMI-EM) consisting of RPMI-1640 medium (Biochrom AG, Berlin, Germany) with $10 \%$ FCS, $100 \mathrm{U} / \mathrm{ml}$ penicillin, $100 \mu \mathrm{g} / \mathrm{ml}$ streptomycin, $1 \%$ sodium pyruvate $(100 \mathrm{mM}$, Biochrom AG), and 1\% non-essential amino acids (100-fold concentration, Biochrom AG). Cells were cultured at $37^{\circ} \mathrm{C}$ with $5 \% \mathrm{CO}_{2}$ in culture flasks. Medium was replaced every other day and passaging was performed after reaching $70-80 \%$ confluence by trypsinization, with subsequent washing and seeding in new flasks or treatment wells. Experiments were performed using cells in the exponential growth phase.

Exposure to celecoxib and simvastatin. The half-maximal inhibitory concentrations $\left(\mathrm{IC}_{50}\right)$ of celecoxib (Pfizer Pharma PFE, Berlin, Germany) and simvastatin (MIP Pharma, Blieskastel, Germany) on PE/CA-PJ 41 were evaluated with the MTT assay (Fig. 1). To this end, PE/CA-PJ-41 cells were treated with $40 \mu \mathrm{M} / \mathrm{ml}$ celecoxib, $50 \mu \mathrm{M} / \mathrm{ml}$ simvastatin or the combination of both. Analytical assays were performed after $24 \mathrm{~h}$ of incubation.

3-(4,5-Dimethylthiazol-2-yl)-2,5-diphenyltetrazolium bromide (MTT) assay. After 3 days of co-culture, the MTT (Sigma-Aldrich, Taufkirchen, Germany) colorimetric staining method was performed according to Mosmann (42) to determine cell viability. Cells were seeded at 10,000 cells per well in a 12-well plate. All wells were incubated with $1 \mathrm{ml}$ MTT $(1 \mathrm{mg} / \mathrm{ml})$ for $5 \mathrm{~h}$ at $37^{\circ} \mathrm{C}$ and $5 \% \mathrm{CO}_{2}$. MTT was then removed and $1 \mathrm{ml}$ isopropanol was added, followed by another incubation period of $1 \mathrm{~h}$ at $37^{\circ} \mathrm{C}$ and $5 \% \mathrm{CO}_{2}$. Measurement of the color conversion of the blue formazan dye was performed using a multi-plate reader (Titertek Multiskan PLUS MK II; Thermo
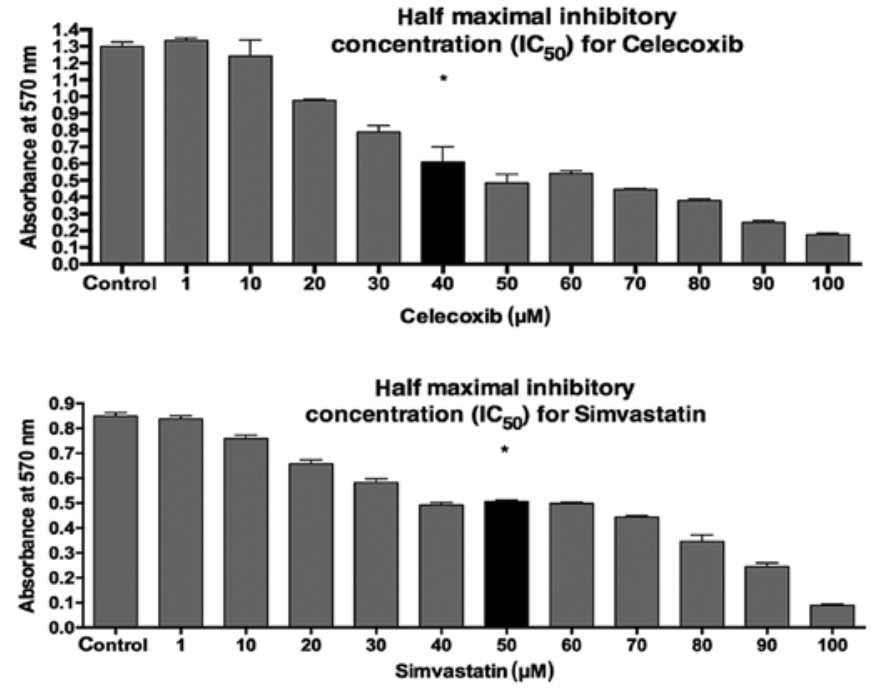

Figure 1. Evaluation of $\mathrm{IC}_{50}$ for celecoxib (upper graphic) and simvastatin (lower graphic) using the MTT assay. Concentrations were identified as $40 \mu \mathrm{M}$ for celecoxib and $50 \mu \mathrm{M}$ for simvastatin (highlighted with asterisk and black column).

Labsystems, Thermo Fisher Scientific, Inc., Darmstadt, Germany) at a wavelength of $570 \mathrm{~nm}$.

Colony assay. PE/CA-PJ 41 were seeded into 6-well plates at a concentration of $2.5 \times 10^{3}$ cells $/$ well in triplicate. Celecoxib $(40 \mu \mathrm{M}), 50 \mu \mathrm{M}$ simvastatin or the combination of both were added to defined well plates. PE/CA-PJ 41 cultivated in RPMI-EM served as the control. Cells were incubated for 14 days. After 2 weeks the well plates were stained with crystal violet, and colonies were counted manually.

Annexin V-propidium iodide test. The BD Pharmingen Annexin V-APC kit (BD Biosciences, Heidelberg, Germany) was used to evaluate apoptosis on HLaC78 and PE/CA-PJ 41. After 3 days of co-culture, cells in suspension and adherent cells were harvested, then washed twice with PBS and resuspended in 1:10 binding buffer [0.1 M HEPES (Sigma-Aldrich) $(\mathrm{pH} 7.4)$, $1.4 \mathrm{M} \mathrm{NaCl}, 25 \mathrm{mM} \mathrm{CaCl}_{2}$ ] at a concentration of $1 \times 10^{6}$ cells $/ \mathrm{ml}$. Aliquots of this cell suspension $\left(100 \mu 1 ; 1 \times 10^{5}\right.$ cells) were then transferred to a $5 \mathrm{ml}$ culture tube. Propidium iodide $(5 \mu \mathrm{l})$ and Annexin V-APC (5 $\mu \mathrm{l})$ were added to each aliquot. After 15 min of incubation at room temperature in the dark, the cells were resuspended with $400 \mu 1$ 1:10 binding buffer. A FACSCanto flow cytometer was used to analyze the samples with BD FACSDiva version 5.0.3 software (BD Biosciences). Only cells with damaged membranes were stained by propidium iodide.

Cell cycle analysis. To analyze the effect of celecoxib and salinomycin on the cell cycle of PE/CA-PJ-41 and HLaC78, $1 \times 10^{5}$ cells were cultivated in 12 -well plates in triplicate. Following a $48 \mathrm{~h}$ period, PE/CA-PJ-41 cells were trypsinized and washed twice with cold PBS. Cells were then fixed in $1 \mathrm{ml}$ of $70 \%$ cold ethanol in test tubes and incubated for $2 \mathrm{~h}$ at $4{ }^{\circ} \mathrm{C}$ in the dark. After incubation, cells were centrifuged at $500 \mathrm{x} \mathrm{g}$ for $5 \mathrm{~min}$ at $4^{\circ} \mathrm{C}$ and resuspended in $500 \mu \mathrm{l}$ propidium iodide (BD Bioscience). After another incubation at $4^{\circ} \mathrm{C}$ in the dark 


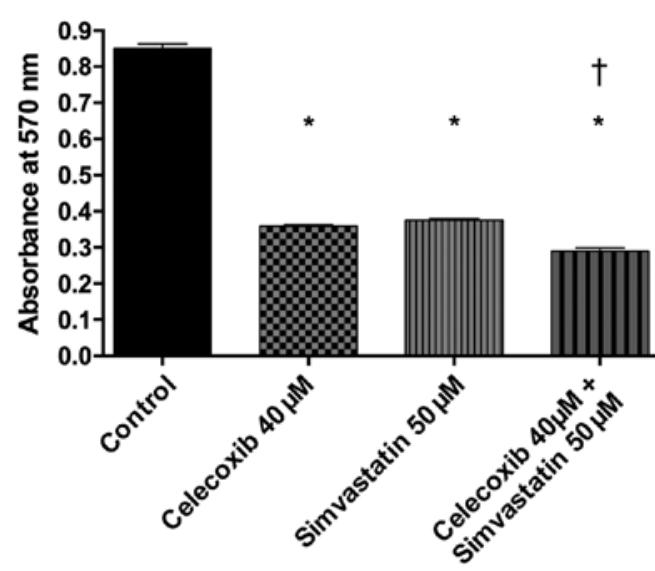

Figure 2. Evaluation of viability using the MTT assay. Lower viability of all three medication groups compared to the control ( $\mathrm{p}<0.0001)$. Cross indicates a significant difference of combination therapy compared to both monotherapies $(\mathrm{p}<0.0001)$.

for $15 \mathrm{~min}$, cells were analyzed with flow cytometry within $1 \mathrm{~h}$. PE/CA-PJ-41 cultivated in RPMI-EM served as the control.

$I L-6 / I L-8 E L I S A$. For measurement of the secretion of IL-6 and IL-8, the supernatants were collected (centrifugation, $150 \mathrm{xg}$ for $5 \mathrm{~min}$ at $37^{\circ} \mathrm{C}$ ) after 3 days of co-culture and stored at $-20^{\circ} \mathrm{C}$ in sterile tubes until further use. RPMI-EM served as the control. Human IL-6 and IL-8 kits (catalog nos. 950.030.192 and 950.050.192, respectively; Diaclone SAS, Besançon, France) were used and the experiments were performed in duplicate. The ELISA plate was read at $450 \mathrm{~nm}$ (Titertek Multiskan PLUS MK II). The concentrations of IL-6 and IL-8 were determined by constructing a standard curve using recombinant IL-6 and IL-8.

Statistical analysis. The data collected was transferred to standard spreadsheets and statistically analyzed using GraphPad Prism software (version 4.0; GraphPad Software, Inc., San Diego, CA, USA). Data are presented as the mean \pm standard deviation of three experiments, unless otherwise stated. The Gaussian distribution was tested via first column analysis. One-way analysis of variance followed by Tukey's multiple comparison test was used. Additionally, multiplicity adjusted p-values were determined. $\mathrm{p}<0.05$ was used to indicate a statistically significant difference. The combination index (CI) was applied to evaluate the interaction between celecoxib and
Combination index (MMT)

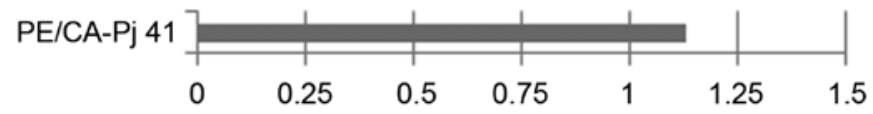

Figure 3. Combination index (CI) for PE/CA-PJ 41 from the data of MTT assay. CI was calculated at 1.13 , indicating a moderate additive effect. Synergy, <0.85; additivity, 0.85-1.15; antagonism, $>1.15$.

simvastatin for PE/CA-PJ 41. CI analysis provides qualitative information on the nature of drug interaction, and the CI index, a numerical value calculated as described below, also provides a quantitative measure of the extent of drug interaction (43).

$$
\mathrm{CI}=\mathrm{C}_{\mathrm{A}, \mathrm{X}}: \mathrm{IC}_{\mathrm{X}, \mathrm{A}}+\mathrm{C}_{\mathrm{B}, \mathrm{X}}: \mathrm{IC}_{\mathrm{X}, \mathrm{B}}
$$

$\mathrm{C}_{\mathrm{A}, \mathrm{X}}$ and $\mathrm{C}_{\mathrm{B}, \mathrm{X}}$ are the concentrations of drug $\mathrm{A}$ and drug $\mathrm{B}$ used in combination to achieve $\mathrm{x} \%$ drug effect $\left(\mathrm{IC}_{75}, \mathrm{IC}_{50}\right) . \mathrm{IC}_{\mathrm{X}, \mathrm{A}}$ and $\mathrm{IC}_{\mathrm{X}, \mathrm{B}}$ are the concentrations required for single agents to achieve the same effect. A CI of $<0.85$ was deemed to indicate synergy, a CI of $>1.15$ was deemed to indicate antagonism. Additive effects were assumed at an CI between 0.85 and 1.15.

\section{Results}

MTT assay. Viability of PE/CA-PJ-41 cells was analyzed using the MTT assay (Fig. 2). It revealed a significantly lower viability after addition of celecoxib, simvastatin and the combination of both compared to the control group $(\mathrm{p}<0.05$ for all three). The combination of treatment with celecoxib and simvastatin also proved to decrease tumor cell viability significantly more compared to celecoxib and simvastatin alone ( $p<0.05$ for both). Between treatment with celecoxib and simvastatin, no significant difference was found ( $p>0.05$ ). The CI was calculated as 1.13 , indicating a moderate additive effect (Fig. 3).

Colony assay. Tumor cell proliferation was analyzed using a colony assay (Figs. 4 and 5). Treatment with celecoxib, simvastatin and the combination of both showed significantly reduced cell colonies compared to the control group $(\mathrm{p}<0.05$ for all three). Colony forming was higher when incubated with celecoxib alone versus simvastatin alone $(p<0.05)$. The combination of both drugs showed no significant difference compared to celecoxib ( $\mathrm{p}>0.05)$ or simvastatin $(\mathrm{p}>0.05)$ alone.

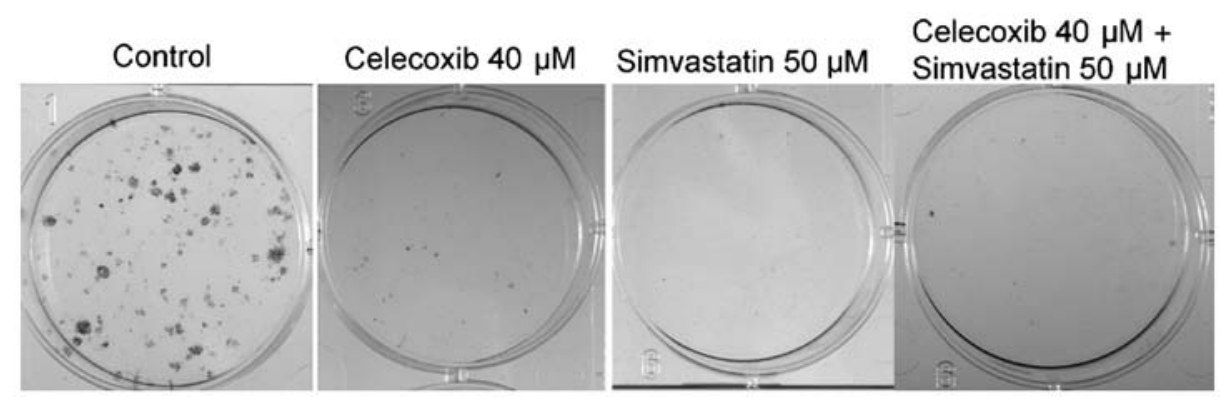

Figure 4. Dishes used in the colony assay after staining 14 days after seeding. Compared to the control, celecoxib alone shows fewer cell colonies, while simvastatin alone and the combination of both have almost no colony formation. 


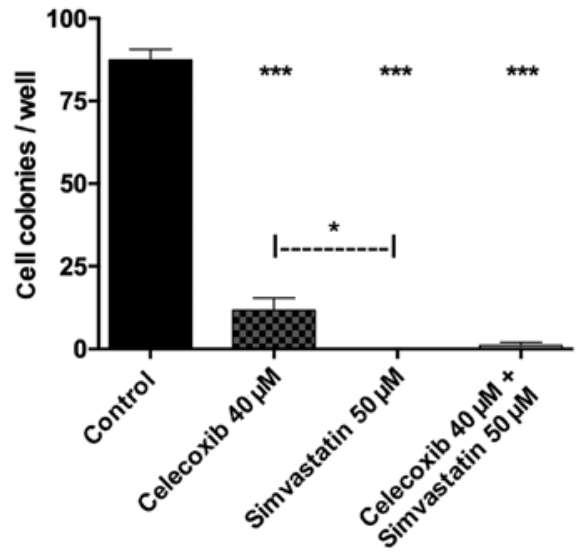

Figure 5. Statistical evaluation of the colony assay. All three medication groups have significantly lower colony formation compared to the control $\left({ }^{* * *} \mathrm{p}<0.0001\right.$ for all). Moreover, between celecoxib and simvastatin the difference is significant ( $\mathrm{p}=0.0459)$. For the combination therapy, no significant differences compared to celecoxib $(\mathrm{p}=0.068)$ or simvastatin $(\mathrm{p}=0.9918)$ alone could be identified.

Annexin V-propidium iodide test. Annexin V-propidium iodide analysis of PE/CA-PJ 41 (Fig. 6A) and HLaC78 (Fig. 6B) revealed enhanced apoptosis and necrosis after simvastatin treatment alone and after the combination of both compared to the control group ( $\mathrm{p}<0.05$ for both). The combination of both drugs induced higher rates of apoptosis and necrosis compared to simvastatin and celecoxib alone $(\mathrm{p}<0.05)$. Addition of celecoxib alone had no significant difference on apoptosis or necrosis compared to the control $(\mathrm{p}>0.05)$.

Cell cycle analysis. For both cell lines used, cell cycle analysis showed a significant increase in cells in G0/G1-phase when treated with celecoxib and simvastatin in combination compared to the control group $(\mathrm{p}<0.05)$, while celecoxib $(p>0.05)$ and simvastatin $(p>0.05)$ alone had no significant effect. The effect of the combination therapy was also significant compared to celecoxib $(\mathrm{p}<0.05)$ and simvastatin $(\mathrm{p}<0.05)$ alone (Fig. 7A and B).

Quantitative analysis of $I L-6$. Treatment with celecoxib, simvastatin and the combination of both all showed a lower secretion of IL- 6 compared to the control group $(\mathrm{p}<0.05$ for all three). Addition of simvastatin proved to decrease IL-6 secretion significantly more than celecoxib $(\mathrm{p}<0.05)$. The combined treatment of both drugs in turn showed less IL-6 than celecoxib $(\mathrm{p}<0.05)$ or simvastatin alone $(\mathrm{p}<0.05 ;$ Fig. 8$)$.

Quantitative analysis of IL-8. Treatment with celecoxib, simvastatin and the combination of both all revealed a lower secretion of IL-8 compared to the control group $(\mathrm{p}<0.05$ for all three). Incubation with celecoxib showed significantly
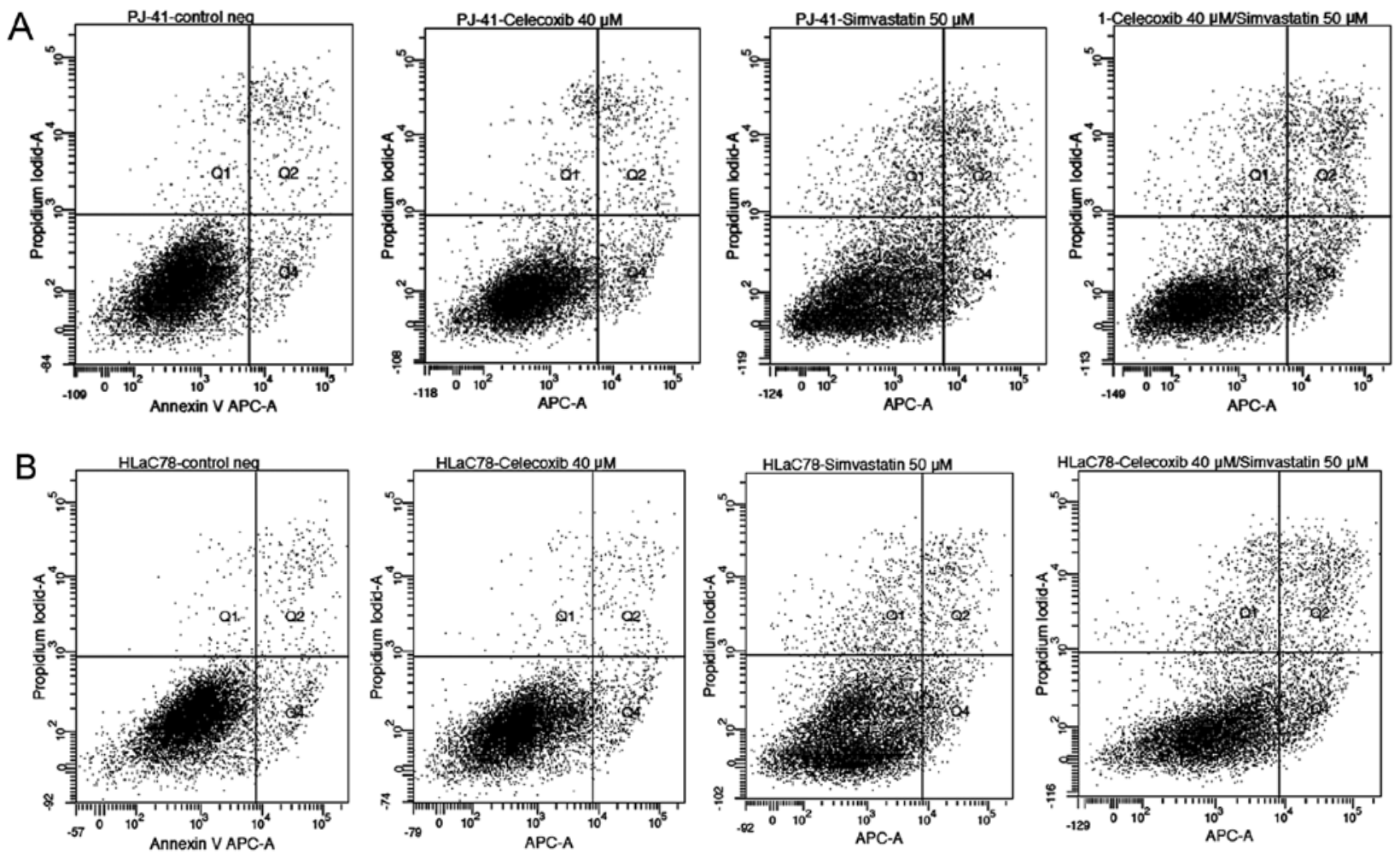

Figure 6. (A) Annexin V-propidium iodide analysis of PE/CA-PJ 41. Apoptosis and necrosis is increased for simvastatin as well as the combination of both compared to the control group ( $<<0.05$ for both). The combination of both drugs also showed higher rates of apoptosis and necrosis compared to simvastatin and celecoxib alone $(\mathrm{p}<0.05)$. Celecoxib alone showed no significant difference in apoptosis or necrosis compared to the control ( $\mathrm{p}>0.05$; data not shown). Q1,\% of damaged cells; Q2,\% of necrotic cells; Q3, \% of viable cells; Q4, \% of apoptotic cells. APC-A, allophycocyanin-A. (B) Annexin V-propidium iodide analysis of HLaC78. Apoptosis and necrosis is increased for simvastatin as well as the combination of both compared to the control group (p<0.05 for both). The combination of both drugs also showed higher rates of apoptosis and necrosis compared to simvastatin and celecoxib alone $(\mathrm{p}<0.05)$. Celecoxib alone showed no significant difference in apoptosis or necrosis compared to the control ( $\mathrm{p}>0.05$; data not shown). Q1, \% of damaged cells; Q2, \% of necrotic cells; Q3, \% of viable cells; Q4, \% of apoptotic cells. APC-A, allophycocyanin-A. 

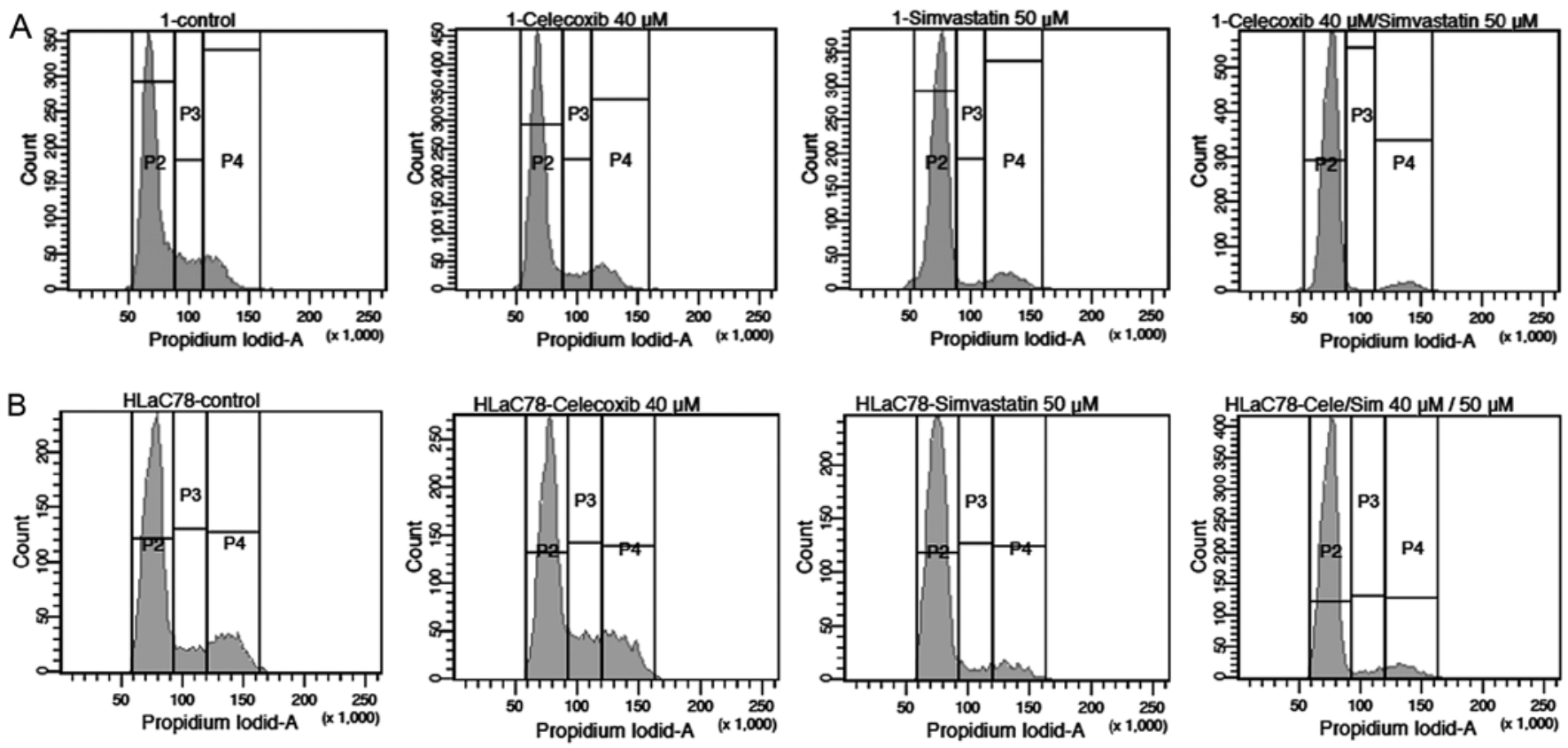

Figure 7. (A) Cell cycle analysis of PE/CA-PJ 41. A significant increase in cells in G0/G1-phase when treated with celecoxib and simvastatin in combination compared to the control group $(\mathrm{p}=0.0001)$, while celecoxib $(\mathrm{p}=0.3058)$ and simvastatin $(\mathrm{p}=0.2266)$ alone had no significant effect. The effect of the combination therapy was also significant compared to celecoxib ( $\mathrm{p}=0.0004)$ and simvastatin ( $\mathrm{p}=0.0005)$ alone (data not shown). P2, cells in $\mathrm{G} 0 / \mathrm{G} 1-\mathrm{phase}$; $\mathrm{P}$, cells in S-phase; P4, cells in G2-phase. (B) Cell cycle analysis of HLaC78. A significant increase in cells in G0/G1-phase when treated with celecoxib and simvastatin in combination compared to the control group $(\mathrm{p}=0.0001)$, while celecoxib $(\mathrm{p}=0.266)$ and simvastatin $(\mathrm{p}=0.198)$ alone had no significant effect. The effect of the combination therapy was also significant compared to celecoxib $(\mathrm{p}=0.003)$ and simvastatin $(\mathrm{p}=0.0009)$ alone (data not shown). P2, cells in $\mathrm{G} 0 / \mathrm{G} 1-\mathrm{phase}$; P3, cells in S-phase; P4, cells in G2-phase.

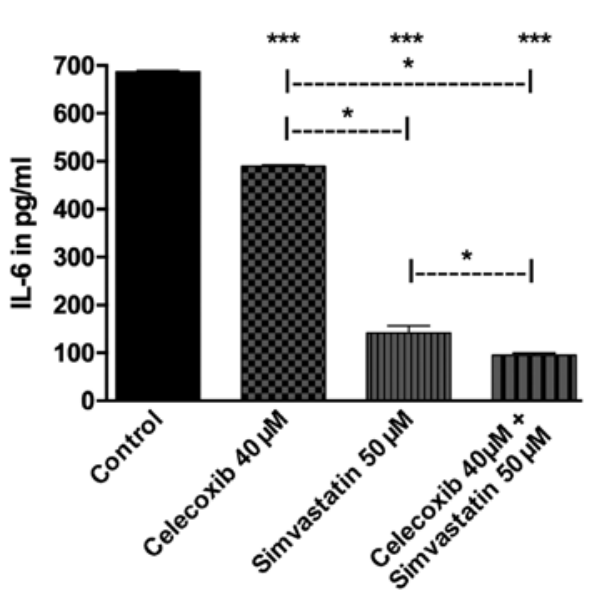

Figure 8. IL-6-ELISA. All three medication groups showed lower IL-6 levels than the control $\left({ }^{* * *} \mathrm{p}<0.0001\right)$. Simvastatin showed decreased IL-6 levels compared to celecoxib ( $\mathrm{p}<0.0001)$. The combination of both also showed lower IL-6 secretion than celecoxib or simvastatin alone ( ${ }^{*} \mathrm{p}<0.0001$ and * $\mathrm{p}=0.0144$, respectively).

decreased IL-8 secretion than with simvastatin $(\mathrm{p}<0.05)$. The combined treatment of both drugs proved to reduce IL-8-production significantly more than celecoxib $(\mathrm{p}<0.05)$ or simvastatin alone ( $\mathrm{p}<0.05$; Fig. 9).

\section{Discussion}

Despite many advances in the therapy of HNSCC, survival rates remain low (44). Anticancer drug treatment for HNSCC today is mostly reserved for palliative chemotherapy regimens, which include cytostatic agents such as cisplatin, 5-FU or

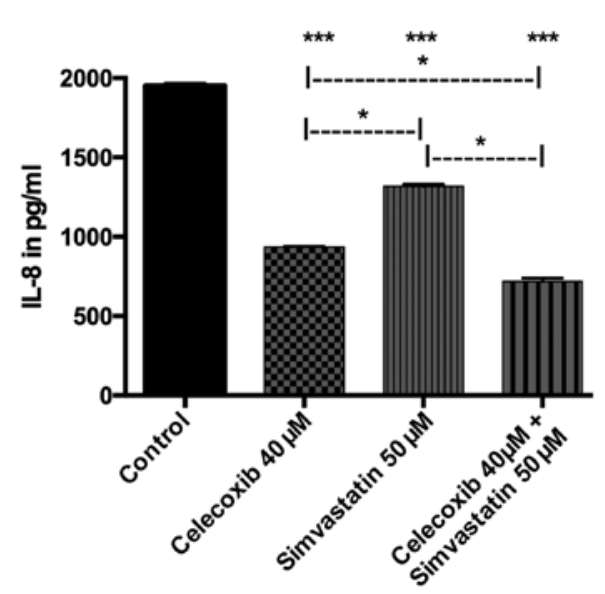

Figure 9. IL-8-ELISA. All three medication groups showed lower IL-8 levels than the control $(* * * 00001)$. Celecoxib showed decreased IL-8 levels compared to simvastatin $\left({ }^{*} \mathrm{p}<0.0001\right)$. The combination of both also showed lower IL-8 secretion than celecoxib or simvastatin alone $\left({ }^{*} \mathrm{p}<0.0001\right.$ for both).

docetaxel as well as monoclonal antibodies such as cetuximab. However, these drugs offer small benefit with respect to progression-free survival, while in turn inducing severe side effects further limiting the use in cancer patients (45). Therefore, research for identifying new treatment options with reduced toxicities is warranted.

Simvastatin is an inhibitor of HNG-CoA reductase, an enzyme of the mevalonate synthesis pathway, which in turn inhibits formation of downstream lipid isoprenoids such as farnesyl pyrophosphate (FFP) and geranylgeranyl pyrophosphate (GGPP) (46). This in turn results in the side effect of 
decreasing cell proliferation via inhibition of Ras oncogenes (47). Statins have also been shown to induce apoptosis, reduce serum-stimulated Ras activity and increase messenger RNA (mRNA) and protein expression of the proapoptotic proteins Bax and Bad in esophageal carcinoma cell lines (48).

NSAIDs in general (21-23), as well as selective COX-2inhibitors (24-26), have already proven to be potent tumor-protective substances in vitro and in vivo. However, relatively high doses of NSAIDs or selective COX-2-inhibitors are needed to achieve the desired effects, which causes problems for long-term therapy due to the cardiovascular risks of these drugs (27-29). Thus, a combination of NSAIDs with other possibly synergistic drugs, for example statins, could be a solution for reducing the required doses for each.

The combination of statins and NSAIDs has already been demonstrated to have synergistic effects on colorectal cancer cells in vitro $(30,31)$ and in an animal model in vivo (32). Yet, as of now few studies have evaluated the effects of this combination therapy on HNSCC cells. Thus, the present study focused on the synergistic effects of celecoxib and simvastatin on HNSCC cells in vitro.

The analyses showed significant reduction in PE/CA-PJ-41 tumor cell proliferation and viability after addition of celecoxib or simvastatin alone, with the effect increasing even more using a combination of both substances. This confirms results of colorectal cancer cells and prostate cancer cells treated with celecoxib and simvastatin in combination $(30-32,46)$. The underlying mechanisms of these anticarcinogenic effects are not completely understood, however.

In the present study, these antitumor effects were mainly caused by apoptosis and, to a much lesser extent, by necrosis. By inhibition of HMG-CoA reductase, statins inhibit the synthesis of isoprenoids essential for membrane localization and subsequent activation of signaling proteins such as Ras, Rho and Rac, leading to increased apoptosis (4). Moreover, the reduction of cholesterol synthesis via statins and their inhibition of the Akt pathway has been shown to promote apoptosis in cancer cells (7). NSAIDs, on the other hand, also have a variety of possible mechanisms that determine their anticarcinogenic properties. Besides inhibition of $\mathrm{Ca}^{2+}$ ATPase activity (18), increase in ceramid levels (49), and inhibition of transcription activity of NFKB (50), NSAIDs have also shown the potential for inhibition of the Akt pathway, as does simvastatin (17). Even in concentrations that do not induce direct inhibition of Akt by celecoxib itself, it could be demonstrated that celecoxib significantly synergized atorvastatin to inhibit Akt-phosphorylation, indicating a pivotal synergistic effect of both substances regarding Akt-pathway-induced apoptosis (46).

In addition, significant cell cycle arrest in G0/G1-phase could be demonstrated for the combination therapy in the present study. Celecoxib has already been shown to induce cell cycle arrest at G1-phase via increased expression of cyclin-dependent kinase (CDK) inhibitors for various tumor cell types $(51,52)$. The combination of atorvastatin and celecoxib has also been demonstrated to cause cell cycle arrest at G0/G1-phase at a significantly higher level than both substances alone (46). Thus, the induction of cell cycle arrest at G0/G1-phase could also be a potential synergistic effect. Since G0/G1-arrest inhibits the proliferation of tumor cells, it is a vital target for anticancer therapeutics. However, whether this G0/G1-arrest is irreversible, as has been described for Terfenadine (53), or perhaps even reversible, remains unclear since the present study only measured one time point after treatment. Preliminary analysis hint at an increase of cyclindependent kinase inhibitors $\mathrm{p} 21^{\mathrm{Cip} / / \text { Waf1 }}$ and $\mathrm{p} 27^{\mathrm{Kipl}}$ as a possible mechanism behind the G0/G1-arrest. However, in the present study no complete analysis of cell cycle protein expression has been conducted, limiting the information in this regard. It will be part of a future investigation at our institution.

The present study also revealed a significantly lower secretion of IL- 6 and IL- 8 by the tumor cells after addition of simvastatin and celecoxib combined rather than alone. IL-6 is a cytokine which, among other functions, induces STAT3 phosphorylation via IL-6 receptors and Janus family kinases (JAK), and is thereby involved in cell proliferation, angiogenesis and apoptosis $(54,55)$. For hepatocellular carcinoma, celecoxib has already been demonstrated to inhibit IL-6/IL-6-receptorinduced JAK2/STAT3 phosphorylation (56). In a study focusing on arthritis, celecoxib significantly reduced secretion of IL-6 and IL-8 in synovial fluid (57). Similarly, simvastatin was also shown to inhibit IL-6 and IL-8 production in rheumatoid arthritis (58). However, the effect of a combination of celecoxib and simvastatin on IL-6-secretion has not been investigated thus far, and in particular not for HNSCC.

Interleukin-8 (IL-8), one of the ELR ${ }^{+}$CXC family of chemokines, is a potent pro-angiogenic factor and its expression is associated with angiogenesis, tumor progression and survival in patients with cancer $(59,60)$. NSAIDs have been shown to have inhibitory effects on angiogenesis for pancreatic tumors in a mouse model, even by COX-independent mechanisms (61), and have proven to inhibit other proangiogenetic factors such as matrixmetalloprotease (MMP)-2 and -9, as well as early growth response factor EGR-1 (62-64). Simvastatin could be demonstrated to inhibit the production of IL-6 and IL-8 as well as cell proliferation in patients with rheumatoid arthritis (58). To our knowledge, the present study is the first to evaluate the effect of a combination of celecoxib and simvastatin on IL-8 production, and therefore the angiogenesis of tumor cells, which may be of great value in the treatment of metastatic cancer considering the critical role of angiogenesis.

Still, there is much controversy about the concentrations of simvastatin and celecoxib used in in vitro experiments, regarding the expected in vivo dose necessary to achieve similar effects in humans (65). Most in vitro studies regarding cancer therapy have come to use concentrations of 40-60 $\mu \mathrm{M}$ of simvastatin (66). Although it is true that the in vitro concentrations generally used in oncologic studies are higher than the expected dose in vivo, there is also the problem of accumulation in the target organ, the liver, which at least partially makes up for the difference in concentrations (67). The same is valid for celecoxib, where the concentrations generally used in vitro are also slightly higher than the expected in vivo doses achievable in humans (68). Therefore, to further reduce possible side effects when examining the co-medication in vivo, lower concentrations should also be tested for possible further synergistic effects in the future.

Since especially simvastatin intervenes in the synthesis of Cholesterol, a key in cellular integrity, there could be possible damage to regular human cells as well. Gauthaman et al, on the other hand, already showed that simvastatin decreased viability 
and proliferation of cancer cells and cancer stem cells, but had no effect on normal human stem cells (69). This, coupled with the years of clinical practice and experience with possible side effects of both substances, may still make it worthwhile to further examine their possible use as anticancer drugs.

In conclusion, it could be demonstrated that a combination of celecoxib and simvastatin has significant synergistic effects on reducing tumor cell proliferation and viability in HNSCC cells in vitro. These antitumor effects are based on apoptosis and cell cycle arrest in G0/G1-phase. Furthermore, a reduction in the secretion of IL- 6 and IL- 8 could be shown, indicating additional ways this synergism works to inhibit tumor growth, such as via antiangiogenesis. At present, medical tumor therapy for HNSCC is still limited. However, since both substances have a good risk-benefit ratio based on their long-term clinical use as lipid-lowering and anti-inflammational drugs, at least in concentrations used in the present study, their combined use for cancer therapy clearly warrants further investigation. Future studies will need to elucidate the intracellular mechanisms behind these effects. Especially analysis of mitogenic and other signaling pathways are relevant targets for further investigations.

\section{Acknowledgements}

This study was supported by the Rudolf Bartling Foundation.

\section{References}

1. Miller KD, Siegel RL, Lin CC, Mariotto AB, Kramer JL, Rowland JH, Stein KD, Alteri R and Jemal A: Cancer treatment and survivorship statistics, 2016. CA Cancer J Clin 66: 271-289, 2016.

2. Siegel RL, Miller KD and Jemal A: Cancer statistics, 2016. CA Cancer J Clin 66: 7-30, 2016.

3. Herrero R, Castellsagué X, Pawlita M, Lissowska J, Kee F, Balaram P, Rajkumar T, Sridhar H, Rose B, Pintos J, et al; IARC Multicenter Oral Cancer Study Group: Human papillomavirus and oral cancer: The International Agency for Research on Cancer multicenter study. J Natl Cancer Inst 95: 1772-1783, 2003.

4. Xiao $\mathrm{H}$ and Yang CS: Combination regimen with statins and NSAIDs: A promising strategy for cancer chemoprevention. Int J Cancer 123: 983-990, 2008.

5. Prasanna P, Thibault A, Liu L and Samid D: Lipid metabolism as a target for brain cancer therapy: Synergistic activity of lovastatin and sodium phenylacetate against human glioma cells. J Neurochem 66: 710-716, 1996.

6. Xia Z, Tan MM, Wong WW, Dimitroulakos J, Minden MD and Penn LZ: Blocking protein geranylgeranylation is essential for lovastatin-induced apoptosis of human acute myeloid leukemia cells. Leukemia 15: 1398-1407, 2001.

7. Zhuang L, Kim J, Adam RM, Solomon KR and Freeman MR: Cholesterol targeting alters lipid raft composition and cell survival in prostate cancer cells and xenografts. J Clin Invest 115: 959-968, 2005

8. Blais L, Desgagné A and LeLorier J: 3-Hydroxy-3-methylglutaryl coenzyme A reductase inhibitors and the risk of cancer: A nested case-control study. Arch Intern Med 160: 2363-2368, 2000.

9. Graaf MR, Beiderbeck AB, Egberts AC, Richel DJ and Guchelaar HJ: The risk of cancer in users of statins. J Clin Oncol 22: 2388-2394, 2004.

10. Friis S, Poulsen AH, Johnsen SP, McLaughlin JK, Fryzek JP, Dalton SO, Sørensen HT and Olsen JH: Cancer risk among statin users: A population-based cohort study. Int J Cancer 114: 643-647, 2005.

11. Olsen JH, Johansen C, Sørensen HT, McLaughlin JK, Mellemkjaer L, Steffensen FH and Fraumeni JF Jr: Lipidlowering medication and risk of cancer. J Clin Epidemiol 52: 167-169, 1999.

12. Kaye JA and Jick H: Statin use and cancer risk in the General Practice Research Database. Br J Cancer 90: 635-637, 2004.
13. Poynter JN, Gruber SB, Higgins PD, Almog R, Bonner JD, Rennert HS, Low M, Greenson JK and Rennert G: Statins and the risk of colorectal cancer. N Engl J Med 352: 2184-2192, 2005.

14. Khurana V, Bejjanki HR, Caldito G and Owens MW: Statins reduce the risk of lung cancer in humans: A large case-control study of US veterans. Chest 131: 1282-1288, 2007.

15. Farwell WR, Scranton RE, Lawler EV, Lew RA, Brophy MT, Fiore LD and Gaziano JM: The association between statins and cancer incidence in a veterans population. J Natl Cancer Inst 100: 134-139, 2008

16. Khurana V, Caldito G and Ankem M: Statins might reduce risk of renal cell carcinoma in humans: Case-control study of 500,000 veterans. Urology 71: 118-122, 2008.

17. Kulp SK, Yang YT, Hung CC, Chen KF, Lai JP, Tseng PH, Fowble JW, Ward PJ and Chen CS: 3-phosphoinositidedependent protein kinase-1/Akt signaling represents a major cyclooxygenase-2-independent target for celecoxib in prostate cancer cells. Cancer Res 64: 1444-1451, 2004.

18. Johnson AJ, Hsu AL, Lin HP, Song X and Chen CS: The cyclooxygenase-2 inhibitor celecoxib perturbs intracellular calcium by inhibiting endoplasmic reticulum $\mathrm{Ca}^{2+}$-ATPases: A plausible link with its anti-tumour effect and cardiovascular risks. Biochem J 366: 831-837, 2002.

19. Luciani MG, Campregher $\mathrm{C}$ and Gasche $\mathrm{C}$ : Aspirin blocks proliferation in colon cells by inducing a G1 arrest and apoptosis through activation of the checkpoint kinase ATM. Carcinogenesis 28: 2207-2217, 2007.

20. Thun MJ,Henley SJ and Patrono C: Nonsteroidal anti-inflammatory drugs as anticancer agents: Mechanistic, pharmacologic, and clinical issues. J Natl Cancer Inst 94: 252-266, 2002.

21. Giardiello FM, Hamilton SR, Krush AJ, Piantadosi S, Hylind LM, Celano P, Booker SV, Robinson CR and Offerhaus GJ: Treatment of colonic and rectal adenomas with sulindac in familial adenomatous polyposis. N Engl J Med 328: 1313-1316, 1993.

22. Labayle D, Fischer D, Vielh P, Drouhin F, Pariente A, Bories C, Duhamel O, Trousset $M$ and Attali P: Sulindac causes regression of rectal polyps in familial adenomatous polyposis. Gastroenterology 101: 635-639, 1991.

23. Nugent KP, Farmer KC, Spigelman AD, Williams CB and Phillips RK: Randomized controlled trial of the effect of sulindac on duodenal and rectal polyposis and cell proliferation in patients with familial adenomatous polyposis. Br J Surg 80: 1618-1619, 1993.

24. Steinbach G, Lynch PM, Phillips RK, Wallace MH, Hawk E, Gordon GB, Wakabayashi N, Saunders B, Shen Y, Fujimura T, et al: The effect of celecoxib, a cyclooxygenase-2 inhibitor, in familial adenomatous polyposis. N Engl J Med 342: 1946-1952, 2000.

25. Bertagnolli MM, Eagle CJ, Zauber AG, Redston M, Solomon SD, Kim K, Tang J, Rosenstein RB, Wittes J, Corle D, et al; APC Study Investigators: Celecoxib for the prevention of sporadic colorectal adenomas. N Engl J Med 355: 873-884, 2006.

26. Arber N, Eagle CJ, Spicak J, Rácz I, Dite P, Hajer J, Zavoral M, Lechuga MJ, Gerletti P, Tang J, et al; PreSAP Trial Investigators: Celecoxib for the prevention of colorectal adenomatous polyps. N Engl J Med 355: 885-895, 2006.

27. Bresalier RS, Sandler RS, Quan H, Bolognese JA, Oxenius B, Horgan K, Lines C, Riddell R, Morton D, Lanas A, et al; Adenomatous Polyp Prevention on Vioxx (APPROVe) Trial Investigators: Cardiovascular events associated with rofecoxib in a colorectal adenoma chemoprevention trial. N Engl J Med 352: 1092-1102, 2005.

28. Kerr DJ, Dunn JA, Langman MJ, Smith JL, Midgley RS, Stanley A, Stokes JC, Julier P, Iveson C, Duvvuri R, et al; VICTOR Trial Group: Rofecoxib and cardiovascular adverse events in adjuvant treatment of colorectal cancer. N Engl J Med 357: 360-369, 2007.

29. Solomon SD, McMurray JJ, Pfeffer MA, Wittes J, Fowler R, Finn P, Anderson WF, Zauber A, Hawk E and Bertagnolli M; Adenoma Prevention with Celecoxib (APC) Study Investigators: Cardiovascular risk associated with celecoxib in a clinical trial for colorectal adenoma prevention. N Engl J Med 352: 1071-1080, 2005.

30. Swamy MV, Cooma I, Reddy BS and Rao CV: Lamin B, caspase-3 activity, and apoptosis induction by a combination of HMG-CoA reductase inhibitor and COX-2 inhibitors: A novel approach in developing effective chemopreventive regimens. Int J Oncol 20: 753-759, 2002. 
31. Agarwal B, Rao CV, Bhendwal S, Ramey WR, Shirin H, Reddy BS and Holt PR: Lovastatin augments sulindac-induced apoptosis in colon cancer cells and potentiates chemopreventive effects of sulindac. Gastroenterology 117: 838-847, 1999.

32. Zheng X, Cui XX, Avila GE, Huang MT, Liu Y, Patel J, Kong AN, Paulino R, Shih WJ, Lin Y, et al: Atorvastatin and celecoxib inhibit prostate PC-3 tumors in immunodeficient mice. Clin Cancer Res 13: 5480-5487, 2007.

33. Hoffmeister M, Chang-Claude $\mathbf{J}$ and Brenner H: Individual and joint use of statins and low-dose aspirin and risk of colorectal cancer: A population-based case-control study. Int J Cancer 121 1325-1330, 2007.

34. Flick ED, Habel LA, Chan KA, Van Den Eeden SK, Quinn VP, Haque R, Orav EJ, Seeger JD, Sadler MC, Quesenberry CP Jr, et al: Statin use and risk of prostate cancer in the California Men's Health Study cohort. Cancer Epidemiol Biomarkers Prev 16: 2218-2225, 2007.

35. Taga T, Hibi M, Hirata Y, Yamasaki K, Yasukawa K, Matsuda T, Hirano T and Kishimoto T: Interleukin-6 triggers the association of its receptor with a possible signal transducer, gp130. Cell 58: 573-581, 1989.

36. He G, Dhar D, Nakagawa H, Font-Burgada J, Ogata H, Jiang Y, Shalapour S, Seki E, Yost SE, Jepsen K, et al: Identification of liver cancer progenitors whose malignant progression depends on autocrine IL-6 signaling. Cell 155: 384-396, 2013.

37. Trikha M, Corringham R, Klein B and Rossi JF: Targeted anti-interleukin-6 monoclonal antibody therapy for cancer: a review of the rationale and clinical evidence. Clin Cancer Res 9: 4653-4665, 2003.

38. Zhang GJ and Adachi I: Serum interleukin-6 levels correlate to tumor progression and prognosis in metastatic breast carcinoma. Anticancer Res 19: 1427-1432, 1999.

39. Zabaleta J, Su LJ, Lin HY, Sierra RA, Hall MC, Sartor AO, Clark PE, Hu JJ and Ochoa AC: Cytokine genetic polymorphisms and prostate cancer aggressiveness. Carcinogenesis 30 : 1358-1362, 2009.

40. Li A, Varney ML and Singh RK: Expression of interleukin 8 and its receptors in human colon carcinoma cells with different metastatic potentials. Clin Cancer Res 7: 3298-3304, 2001.

41. Ren Y, Poon RT, Tsui HT, Chen WH, Li Z, Lau C, Yu WC and Fan ST: Interleukin-8 serum levels in patients with hepatocellular carcinoma: correlations with clinicopathological features and prognosis. Clin Cancer Res 9: 5996-6001, 2003.

42. Mosmann T: Rapid colorimetric assay for cellular growth and survival: Application to proliferation and cytotoxicity assays. J Immunol Methods 65: 55-63, 1983.

43. Chou TC and Talalay P: Quantitative analysis of dose-effect relationships: The combined effects of multiple drugs or enzyme inhibitors. Adv Enzyme Regul 22: 27-55, 1984

44. Chan GG, Tai BC, Liang S, Lim DT and Soo KC: Squamous cell carcinoma of the head and neck (HNSCC) - multi-modality treatment and impact on survival. Asian J Surg 25: 35-40, 2002.

45. Patil V, Joshi A, Noronha V, Deodhar J, Bhattacharjee A, Dhumal S, Chandrakanth MV, Karpe A, Talreja V, Chandrasekharan A, et al: Expectations and preferences for palliative chemotherapy in head and neck cancers patients. Oral Oncol 63: 10-15, 2016

46. Xiao H, Zhang Q, Lin Y, Reddy BS and Yang CS: Combination of atorvastatin and celecoxib synergistically induces cell cycle arrest and apoptosis in colon cancer cells. Int J Cancer 122 2115-2124, 2008.

47. Goldstein JL and Brown MS: Regulation of the mevalonate pathway. Nature 343: 425-430, 1990.

48. Ogunwobi OO and Beales IL: Statins inhibit proliferation and induce apoptosis in Barrett's esophageal adenocarcinoma cells. Am J Gastroenterol 103: 825-837, 2008.

49. Kundu N, Smyth MJ, Samsel L and Fulton AM: Cyclooxygenase inhibitors block cell growth, increase ceramide and inhibit cell cycle. Breast Cancer Res Treat 76: 57-64, 2002.

50. Kim SH, Song SH, Kim SG, Chun KS, Lim SY, Na HK, Kim JW, Surh YJ, Bang YJ and Song YS: Celecoxib induces apoptosis in cervical cancer cells independent of cyclooxygenase using NF-kappaB as a possible target. J Cancer Res Clin Oncol 130: 551-560, 2004

51. Grösch S, Tegeder I, Niederberger E, Bräutigam L and Geisslinger G: COX-2 independent induction of cell cycle arrest and apoptosis in colon cancer cells by the selective COX-2 inhibitor celecoxib. FASEB J 15: 2742-2744, 2001.
52. Kardosh A, Blumenthal M, Wang WJ, Chen TC and Schönthal AH: Differential effects of selective COX-2 inhibitors on cell cycle regulation and proliferation of glioblastoma cell lines. Cancer Biol Ther 3: 55-62, 2004.

53. Liu JD, Wang YJ, Chen CH, Yu CF, Chen LC, Lin JK, Liang YC, Lin SY and Ho YS: Molecular mechanisms of G0/G1 cell-cycle arrest and apoptosis induced by terfenadine in human cancer cells. Mol Carcinog 37: 39-50, 2003.

54. Berishaj M, Gao SP, Ahmed S, Leslie K, Al-Ahmadie H, Gerald WL, Bornmann W and Bromberg JF: Stat 3 is tyrosinephosphorylated through the interleukin-6/glycoprotein 130/Janus kinase pathway in breast cancer. Breast Cancer Res 9: R32, 2007.

55. Bollrath J, Phesse TJ, von Burstin VA, Putoczki T, Bennecke M, Bateman T, Nebelsiek T, Lundgren-May T, Canli O, Schwitalla S, et al: gp130-mediated Stat 3 activation in enterocytes regulates cell survival and cell-cycle progression during colitis-associated tumorigenesis. Cancer Cell 15: 91-102, 2009.

56. Liu Y,Liu A,Li H,Li C and Lin J: Celecoxib inhibits interleukin-6/ interleukin-6 receptor-induced JAK2/STAT3 phosphorylation in human hepatocellular carcinoma cells. Cancer Prev Res (Phila) 4: 1296-1305, 2011

57. Bianchi M, Broggini M, Balzarini P, Franchi S and Sacerdote P: Effects of nimesulide on pain and on synovial fluid concentrations of substance $P$, interleukin- 6 and interleukin- 8 in patients with knee osteoarthritis: Comparison with celecoxib. Int J Clin Pract 61: 1270-1277, 2007.

58. Yokota K, Miyazaki T, Hirano M, Akiyama Y and Mimura T: Simvastatin inhibits production of interleukin 6 (IL-6) and IL-8 and cell proliferation induced by tumor necrosis factor-alpha in fibroblast-like synoviocytes from patients with rheumatoid arthritis. J Rheumatol 33: 463-471, 2006.

59. Yuan A, Yang PC, Yu CJ, Chen WJ, Lin FY, Kuo SH and Luh KT: Interleukin-8 messenger ribonucleic acid expression correlates with tumor progression, tumor angiogenesis, patient survival, and timing of relapse in non-small-cell lung cancer. Am J Respir Crit Care Med 162: 1957-1963, 2000.

60. Masuya D, Huang C, Liu D, Kameyama K, Hayashi E, Yamauchi A, Kobayashi S, Haba R and Yokomise H: The intratumoral expression of vascular endothelial growth factor and interleukin-8 associated with angiogenesis in nonsmall cell lung carcinoma patients. Cancer 92: 2628-2638, 2001.

61. Wei D, Wang L, He Y, Xiong HQ, Abbruzzese JL and Xie K: Celecoxib inhibits vascular endothelial growth factor expression in and reduces angiogenesis and metastasis of human pancreatic cancer via suppression of Sp1 transcription factor activity. Cancer Res 64: 2030-2038, 2004.

62. Lee HC, Park IC, Park MJ, An S, Woo SH, Jin HO, Chung HY, Lee SJ, Gwak HS, Hong YJ, et al: Sulindac and its metabolites inhibit invasion of glioblastoma cells via down-regulation of Akt/PKB and MMP-2. J Cell Biochem 94: 597-610, 2005.

63. Ostrowski J, Wocial T, Skurzak H and Bartnik W: Do altering in ornithine decarboxylase activity and gene expression contribute to antiproliferative properties of COX inhibitors? Br J Cancer 88: 1143-1151, 2003.

64. Peluffo GD, Stillitani I, Rodríguez VA, Diament MJ and Klein SM: Reduction of tumor progression and paraneoplastic syndrome development in murine lung adenocarcinoma by nonsteroidal antiinflammatory drugs. Int J Cancer 110: 825-830, 2004.

65. Björkhem-Bergman L, Lindh JD and Bergman P: What is a relevant statin concentration in cell experiments claiming pleiotropic effects? Br J Clin Pharmacol 72: 164-165, 2011.

66. Gauthaman K, Fong CY and Bongso A: Statins, stem cells, and cancer. J Cell Biochem 106: 975-983, 2009.

67. Thelen KM, Rentsch KM, Gutteck U, Heverin M, Olin M, Andersson U, von Eckardstein A, Björkhem I and Lütjohann D: Brain cholesterol synthesis in mice is affected by high dose of simvastatin but not of pravastatin. J Pharmacol Exp Ther 316: 1146-1152, 2006

68. Lai GH, Zhang Z and Sirica AE: Celecoxib acts in a cyclooxygenase-2-independent manner and in synergy with emodin to suppress rat cholangiocarcinoma growth in vitro through a mechanism involving enhanced Akt inactivation and increased activation of caspases-9 and -3. Mol Cancer Ther 2: 265-271, 2003.

69. Gauthaman K, Manasi N and Bongso A: Statins inhibit the growth of variant human embryonic stem cells and cancer cells in vitro but not normal human embryonic stem cells. Br J Pharmacol 157: 962-973, 2009. 